\title{
Multicultural teaching environment: Problems and specifics of knowledge transfer
}

\author{
Valentine K. Zharov \\ Professor, Head of Department of Fundamental and Applied Mathematics \\ Russian State University for the Humanities \\ Address: 6, Miusskaya Square, Moscow, 125993, Russian Federation \\ E-mail:valcon@mail.ru
}

\section{Yulia V. Taratukhina}

Associate Professor, Department of Innovation and Business in Information Technologies

National Research University Higher School of Economics

Address: 20, Myasnitskaya Street, Moscow, 101000, Russian Federation

E-mail: jtaratuhina@hse.ru

\begin{abstract}
In contemporary society, teachers often have to deal with a multicultural student audience, both in a traditional format, and in the process of online training. In general, the culture of each country has an impact on the educational process and largely determines is. This, in turn, implies a uniqueness of the educational content, objectives, value and tasks of education, teaching methods, pedagogical discourse, specifics of building an educational path, etc.

This paper traces the relationship between the cultural influence and educational practices expressed in target, value and communication formats. Many teachers call attention to the problem of constructive knowledge transfer in a multicultural teaching environment as the main problem in this context, in addition to the specifics of cognitive, communication and psycho-pedagogical factors. However, the multicultural environment is taken to mean not only national differences, but also a different previous professional "background" (this refers to students of master's programs, etc.).

In this paper, we share the experience of selecting criteria for the possibility of building a cultural cognitive model of communication with students (tactical and strategic methods of developing various types of discourse) in order to optimize the teaching process in the multicultural environment. The criteria based on which a new-generation multicultural educational environment is to be built and which is able to provide constructive knowledge transfer are presented as follows: communication criterion (change of traditional communication forms in the "teacher - student" system), methodological criterion (emergence of the cultural and adaptive methods of work with educational information), content criterion (differentiation and possible inhomogeneity of the educational content in the educational process) and information criterion (development and use of educational resources taking into account cultural specifics of information perception and handling). The aforementioned points, in turn, cannot but affect the transformation of some institutes of the existing information and pedagogical environment.
\end{abstract}

Key words: polyculture educational environment, cultural-cognitive profile, educational cross-culture.

Citation: Zharov V.K., Taratukhina Y.V. (2014) Multicultural teaching environment:

Problems and specifics of knowledge transfer. Business Informatics, no. 2 (36), pp. 63-70.

DOI: 10.17323/1998-0663.2016.2.63.70. 


\section{Introduction}

$\mathrm{C}$ urrently a multicultural student audience is by no means an unusual occurrence. This applies both to the traditional educational format and to remote educational practices. As a result of a survey of teachers carried out by the authors, who have professional experience in a multicultural teaching environment, a number of difficulties have been identified. They are specific in particular to these types of student audiences and have no place in monocultural environments. Among these are various familiar models of communication with a teacher, specific features of presenting teaching information and educational content, decision-making, the attitude towards creative approaches in the course work, an ambiguous understanding of the academic pursuits and terminology, the preferred type of monitoring and measuring materials, etc. In this case, we face such the phenomenon of educational cross-culture. In the context of interest to us, educational crossculture is a combination of three elements:

1. teacher culture (national and professional);

2. student culture (national and professional);

3. semiotic environment (of educational institution or online resource) and thesaurus of the course unit.

A multicultural education environment is essentially an educational cross-culture. Educational cross-culture is an environment covering a collection of heterogeneous information and pedagogical environments which are interacting in the format of educational communication and learning activity and are in a "diffuzziness" state. The original cross-culture (culture "native" to an individual) is a semiotic education, discursively expressed in the form of thesauruses and elementary knowledge dictionaries and reflecting the pragmatic specifics of educational communication processes.

In this context, it is reasonable to bear in mind the etic and emic approaches [1] - as approaches providing a means for a both culture-specific and invariable look at the teaching process in the multicultural environment ( Table 1).

Table 1

Differences between etic and emic approaches in the educational context

\begin{tabular}{c|c}
\hline Emic approach & Etic Approach \\
\hline $\begin{array}{c}\text { Studies behavior in the "teacher - } \\
\text { student" system within the system }\end{array}$ & $\begin{array}{c}\text { Studies behavior in the "teacher - } \\
\text { student" system outside the system }\end{array}$ \\
\hline Studies only one culture & $\begin{array}{c}\text { Studies a variety of cultures } \\
\text { in the comparative context }\end{array}$ \\
\hline $\begin{array}{c}\text { Criteria are correlated with the } \\
\text { internal system characteristics }\end{array}$ & $\begin{array}{c}\text { Study criteria are considered } \\
\text { as absolute and universal }\end{array}$ \\
\hline
\end{tabular}

The method of cross-cultural study in the educational process has become an "environmental" method expressed in the study of student micro- and macro-environments. Inasmuch as any study of a person's environment is associated with the re-direction - from an individual to the environment and from the environment to an individual - in order to optimize communication processes in the multicultural teaching environment G. Hofstede's parametric model was selected and is presented in the context of educational situations [2]. The purpose of this article is to present possible diffusion processes in educational environments or knowledge transfer in a multicultural environment using the environment-education language, so that the teaching process may predict reactions of people from different cultural environments. The problems of student adaptation to a foreign environment will be understandable if we are able to adjust our professional pedagogical behavior in communication when communication difficulties come up. In other words, a constructive pedagogical action minimizes culture shock and semantic distortions in the communication environment of the educational cross-culture. What does a teacher need to know for this? The answer to this question is one of the research objectives of cross-cultural didactics.

In previous papers, the authors have formulated the basic provisions of cross-cultural didactics, including the concept of a cultural-cognitive personality and audience profile, national and professional styles of thinking, information handling, culture-specific educational discourse, etc. [3, 4]. Depending on these parameters, an adaptive style of teaching can be selected to understand the cultural and cognitive specifics of a student and, thus, the selection of appropriate content, methods, discourse, monitoring and measuring materials, as well as motivational and axiological determination.

\section{The problem of knowledge transfer in a multicultural audience.}

\section{The specifics of communication in the "teacher - student" system in different cultural groups}

It is culture that largely determines the communication specifics in the "teacher-student" system. In the East, the teaching process is initiated by the Teacher; in the West, the Teacher acts more as a coach, an accompanying person. The theory of G. Hofstede [2] considers all cultural components and determines their impact on the interaction in the learning process (Table 2-5). This data indicates that the higher the power distance, the greater the need to recognize the status of a teacher, 
and the fewer discussions can be conducted with him. In the countries with a very high power distance, a teacher should guide every step of a student, whereas when the distance is reduced the initiative passes to the student. The higher the index of community spirit, the worse the activity in group discussions, and a student should be more involved in the process by the teacher. When teaching in masculine society, a competition and result are encouraged; in feminine society, the student's behavior alone is often awarded. In countries trying to avoid uncertainty, the teacher should clearly define the problem as much as possible, the method of its resolution, terms and criteria of evaluation of students. In cultures focusing on a long-term time horizon, students are seeking higher education, primarily because of their commitment to parents and society, and not due to their needs or desires.

\section{Distance power in the context of the educational process}

\begin{tabular}{l|l}
\multicolumn{1}{c|}{ Low distanee power } & \multicolumn{1}{c}{ High distanoe power } \\
\hline $\begin{array}{l}\text { Student-centered model. } \\
\text { Initiative is encouraged. }\end{array}$ & $\begin{array}{l}\text { Teacher-centered model. } \\
\text { Initiative is not encouraged } \\
\text { and comes from the teacher. }\end{array}$ \\
\hline $\begin{array}{l}\text { Communication is initiated } \\
\text { by students. }\end{array}$ & $\begin{array}{l}\text { Communication is initiated } \\
\text { by the teacher. }\end{array}$ \\
\hline $\begin{array}{l}\text { The teacher encourages his } \\
\text { students to select their own } \\
\text { way of leaning. }\end{array}$ & $\begin{array}{l}\text { Students build an educational } \\
\text { path based on pre-agreed } \\
\text { models. }\end{array}$ \\
\hline $\begin{array}{l}\text { Students are allowed to come into } \\
\text { conflict with and criticize the teacher. }\end{array}$ & $\begin{array}{l}\text { Students are not allowed } \\
\text { to come into conflict with } \\
\text { and criticize the teacher. }\end{array}$ \\
\hline $\begin{array}{l}\text { The learning efficiency is a two-sided } \\
\text { process. Permanent feedback } \\
\text { and interactivity are important. }\end{array}$ & $\begin{array}{l}\text { Learning efficiency depends } \\
\text { on the teacher and is subject } \\
\text { to him. }\end{array}$ \\
\hline
\end{tabular}

\section{"Individualism - collectivism" parameters in the educational process}

\begin{tabular}{l|l}
\hline \multicolumn{1}{c|}{ Collectivists } & \multicolumn{1}{c}{ Individualists } \\
\hline $\begin{array}{l}\text { Students speak only when asked } \\
\text { and encouraged by the teacher. }\end{array}$ & $\begin{array}{l}\text { Any question may be a discussion } \\
\text { in nature. }\end{array}$ \\
\hline $\begin{array}{l}\text { Individual speaking is encouraged } \\
\text { only in small groups }\end{array}$ & $\begin{array}{l}\text { Individual speaking and opinions } \\
\text { are always encouraged. }\end{array}$ \\
\hline $\begin{array}{l}\text { Harmony and emotional comfort } \\
\text { are dominant in the learning } \\
\text { process. }\end{array}$ & $\begin{array}{l}\text { Confrontation, clash of opinions } \\
\text { and disagreements are a normal } \\
\text { part of the learning process. }\end{array}$ \\
\hline $\begin{array}{l}\text { Neither the teacher nor the student } \\
\text { should "lose face" in educational } \\
\text { communication. }\end{array}$ & $\begin{array}{l}\text { "Loss of face" is a sign } \\
\text { of professional incompetence. }\end{array}$ \\
\hline $\begin{array}{l}\text { The teacher can give an easy time } \\
\text { in some cases, making allowance } \\
\text { for an individual relation. }\end{array}$ & $\begin{array}{l}\text { Common requirements } \\
\text { for everybody. }\end{array}$ \\
\hline
\end{tabular}

Table 2.

Table 3
Table 4.

Feminine and masculine measures in the context of educational communications

\begin{tabular}{l|l}
\hline \multicolumn{1}{c|}{ Feminine cultures } & \multicolumn{1}{c}{ Masculine oultures } \\
\hline Orientation to an average student & Orientation to the best student \\
\hline $\begin{array}{l}\text { A feature like an ability to adapt to } \\
\text { the team is considered to be valuable. }\end{array}$ & $\begin{array}{l}\text { Academic success is } \\
\text { considered to be valuable. }\end{array}$ \\
\hline $\begin{array}{l}\text { Conflict-free and ability to work } \\
\text { in team. }\end{array}$ & $\begin{array}{l}\text { Ability to present own achieve- } \\
\text { ments and unique character. }\end{array}$ \\
\hline $\begin{array}{l}\text { Correct behavior, moderation in all } \\
\text { things are encouraged. }\end{array}$ & $\begin{array}{l}\text { Distinguishing their team } \\
\text { is encouraged. }\end{array}$ \\
\hline $\begin{array}{l}\text { Students select subjects based } \\
\text { on their personal interests }\end{array}$ & $\begin{array}{l}\text { Students select subjects, } \\
\text { focusing on their benefit } \\
\text { for their future career. }\end{array}$ \\
\hline
\end{tabular}

\begin{tabular}{l|l}
\hline \multicolumn{1}{c|}{ Low } & \multicolumn{1}{c}{ High } \\
\hline $\begin{array}{l}\text { Students feel comfortable outside } \\
\text { the schedule and regulations. }\end{array}$ & $\begin{array}{l}\text { Students feel comfortable under a } \\
\text { tough schedule and regulations. }\end{array}$ \\
\hline $\begin{array}{l}\text { The teacher may say, "I do not } \\
\text { know." }\end{array}$ & $\begin{array}{l}\text { The teacher must be competent } \\
\text { in everything. }\end{array}$ \\
\hline $\begin{array}{l}\text { A good teacher use plain } \\
\text { language. }\end{array}$ & $\begin{array}{l}\text { A good teacher uses academic } \\
\text { language. }\end{array}$ \\
\hline $\begin{array}{l}\text { Students prefer an innovative } \\
\text { approach. }\end{array}$ & $\begin{array}{l}\text { Students are encouraged to be } \\
\text { accurate and compliant with the } \\
\text { predefined requirements. }\end{array}$ \\
\hline $\begin{array}{l}\text { Teachers consider disagreements } \\
\text { on subject issues a stimulating } \\
\text { factor. }\end{array}$ & $\begin{array}{l}\text { Teachers consider disagreement } \\
\text { on subject issues as personal } \\
\text { disloyalty. }\end{array}$ \\
\hline
\end{tabular}

During the authors' theoretical research and its practical approval, a model cultural cognitive profile of a student is proposed, consisting of cognitive, emotional and cultural components and enabling us to predict specifics of teaching activity in the multicultural environment. This model enables a student to constructively build his individual educational path, and enables a teacher to ensure necessary adaptation of the educational content, methods, test materials, communication strategies, etc.

\section{Cultural - cognitive profile of a multicultural student audience}

The tables above make it possible to construct a cultural-cognitive profile of a student (if necessary, a group) and select techniques of effective teamwork. Thus, it is 
possible to select a communication strategy in each subgroup of the study group. Based on these tables, the first class assignments for submission can be also done, e.g. in mathematics using the mother tongue for each student (taking into account that the Russian language is almost a mother tongue in the subgroup of students from CIS countries,). The authors always selected mathematics as the first assignment for submission as a carrier of abstract knowledge with the universal semiotic system and, therefore, having the least amount of stress component in communication with students. The assignment for submission is divided into three levels of complexity; the choice is free. Only some parameters of interest to us in terms of a specific situation of the pedagogical process or research can be taken from the proposed scheme for the model.

As a result, the cultural-cognitive models of students and their teaching style can be "derived". Let us cite as an example a quite limited and polar vision of features of the educational communication in a culturally-specific context. In practice, there can be a good many options ( Table 6).

\section{Philosophy of pedagogical constructivism in a multicultural environment}

The educational process in a multicultural environment is provided at three levels

1) "Person-to-person" level (face-to-face communication);

2) "Person-to-electronic educational milieu (EEM)" level (remote or mixed communication);

3) "Adaptive learning content - invariable learning content" level.

At the "person-to-person" level, as mentioned above, depending on the cultural-cognitive profile, a learning style, appropriate content, methods, discourse, monitoring and measuring materials, motivational and axiological determination can be selected. In particular, methods and techniques of interactive didactic support of students in a virtual multicultural teaching environment are of great interest. The consideration of cultural and pragmatic aspects in designing the structure, content and interface of electronic textbooks and teaching environment, implying a set of pedagogical instruments

Table 6.

Criteria for building communication in a multicultural educational environment

\begin{tabular}{|c|c|c|}
\hline Briteria & "Western" cultures & "Won-Western" cultures \\
\hline $\begin{array}{l}\text { Forms and specifics } \\
\text { of structuring } \\
\text { information }\end{array}$ & $\begin{array}{l}\text { A keynote of verbal-audio and visual type of information } \\
\text { perception; tendency to abstraction and search for } \\
\text { differences; deductive method of thinking; context } \\
\text { independence; information framing - accurate } \\
\text { classification and the tree of knowledge }\end{array}$ & $\begin{array}{l}\text { A keynote of audio and kinesthetic style of information } \\
\text { perception; tendency to search for similarities; inductive } \\
\text { method of thinking; context dependence; information framing } \\
\text { - full (not always accurate) picture of what is happening; } \\
\text { use of intuition and figurative-narrative discourse }\end{array}$ \\
\hline Methods used & $\begin{array}{l}\text { Heuristic and problem-search techniques; paradigms } \\
\text { of handling teaching information - interactive, discussion, } \\
\text { debates. }\end{array}$ & $\begin{array}{l}\text { Receptive and reproductive methods; paradigms of } \\
\text { handling teaching information - information broadcast. }\end{array}$ \\
\hline $\begin{array}{l}\text { Specifics of educational } \\
\text { content }\end{array}$ & $\begin{array}{l}\text { Interactive, multimedia available for additions } \\
\text { and corrections }\end{array}$ & Basically, text content which usually cannot be adjusted \\
\hline Teaching process & Interactive, student-centered & One-sided, teacher-centered \\
\hline $\begin{array}{l}\text { Relation to errors during the } \\
\text { learning process }\end{array}$ & $\begin{array}{l}\text { Errors are perceived as a natural part of the learning } \\
\text { process }\end{array}$ & Errors are often associated with "loss of face" \\
\hline $\begin{array}{l}\text { General characteristics of } \\
\text { monitoring and measuring } \\
\text { materials (MMM) }\end{array}$ & $\begin{array}{l}\text { Selection of one possibility or the author's position } \\
\text { on the issue }\end{array}$ & $\begin{array}{l}\text { Aimed at broadcasting specific answers, almost complete } \\
\text { lack of assignments showing the author's position } \\
\text { and creativity }\end{array}$ \\
\hline Communication content & "Low-context" cultures & "High-context" cultures \\
\hline $\begin{array}{l}\text { Discourse objectives } \\
\text { and values }\end{array}$ & Expression of individuality & Maximum unity with the team, preservation of harmony \\
\hline Dominant styles of discourse & Discussions and debates & Narrative \\
\hline $\begin{array}{l}\text { Dominant emotional } \\
\text { parameters of discourse }\end{array}$ & $\begin{array}{l}\text { The message content is primary, the context is } \\
\text { secondary. Cognitive style of information exchange. } \\
\text { Moderation, self-control }\end{array}$ & $\begin{array}{l}\text { Context plays a dominant role. More significant is } \\
\text { "as they say", and not "what they say". Avoidance } \\
\text { of discursive confrontations }\end{array}$ \\
\hline Typical discursive models & $\begin{array}{l}\text { Linear argumentation based on facts. } \\
\text { "The fact-fact-fact-conclusion" (induction) }\end{array}$ & $\begin{array}{l}\text { An extensive argumentation. } \\
\text { "The conclusion is the evidence" (deduction). }\end{array}$ \\
\hline
\end{tabular}


(specifics of motivation, specifics of presenting educational materials, processing, monitoring, and feedback) is of no little interest.

At the "person-to-EEM" level, consideration is given to problems of educational cross-culture in the process of remote or blended learning. It is necessary to highlight the main areas of education "smartization":

$\diamond$ developing cultural intelligence, forming and building teachers' competence in the area of cross-cultural didactics, learning problems of the best practices with multicultural audiences;

$\diamond$ systematic understanding, the constructive building of an individual educational path in EEM, adapting and using the best international practices in this area;

$\diamond$ problem of an appropriate selection of multimedia technologies and teaching methods for various cultural groups;

$\diamond$ role of unique features of the learning style when interacting with intelligent tutorial systems.

"Adaptive educational content - invariant educational content". Adaptation means an adaptation of educational information, methods and monitoring and measuring materials to the specifics of a student, as well as compilation of cultural-specific elementary dictionaries on the subject (the ambiguity of terminology in different languages). The invariant content implies a compilation of universal elementary dictionaries in subjects or semantic maps.

Therefore, at the first level of the educational process, it is important to develop cultural intelligence in a multicultural environment as an ability of educational communication subjects to understand little-known contexts, and adapt to them; at the second level - EEM having a cultural intelligence should be designed; and at the third level - an adaptive, in some cases, on the contrary, an invariant educational content (elementary dictionaries of knowledge in subjects) should be formed. This multi-step approach enables us to make the knowledge transfer process in a multicultural environment more constructive.

Based on the definitions of relevant subjects of academic disciplines, their connection can be searched for. The educational experience suggests the need to search for subject domain models (either specific or abstract) allowing us to interpret the knowledge studied. Therefore, generally a problem of intersubject connections in various schools, i.e. secondary and higher, comes up. It should be noted that the concept of "interdisciplinary connection" is more general than the concept of "intersubject connections". The latter concept is interpreted by us as a connection between the scientific knowledge subjects learned in course units. Therefore, the problem discussed in this article can be extended to the inter-subject connection of mathematics with the mother tongue. In other words, at a level of development of the invariant educational content we design an environment of quite predictable set of reactions. While investigating the language relationship, we solve several tasks: determining the performance level (mathematics), defining an emotional component of learning (interest, sociability, goal setting), preference in decision making. Having obtained answers to these questions, we have the possibility to adjust the communication strategy in the real educational process in accordance with the strategies set out in Tables 3-5. The cross-curriculum connection is provided at a level of elementary concepts of the subjects, i.e. mathematics and mother tongue. To do this, an elementary dictionary (if possible) or a minimum first-level dictionary should be created, with a correspondence set up afterwards between them. It is known that the elementary mathematics dictionary studied in secondary school was proposed in the paper [5].

The first-level concepts of a minimum dictionary can be formed in a natural way, using elementary concepts. Depending on the learning needs, it is possible to construct the following levels of concepts using from fifteen to nineteen concepts of the elementary dictionary, thereby forming the following levels of knowledge. Further on, the words from the elementary dictionary should be translated into the verbal environment native for a student through examples, thereby fixing the "islands" of stable knowledge in a learning environment new for him. This, in turn, on the one hand, entails a reduction of the stress load on a student in the learning process, and on the other hand, contributes to the study of theoretical and practical material in the new language environment.

The educational environment model can be built as a linguistic model based on papers of K.S. Fu and L.A. Zade [6]. Let us assume that $A=\left\{a_{1}, a_{2}, \ldots, a_{13}\right\}$ are words of the elementary dictionary; $B_{n}$ is a set of words of the natural dictionary, which are not terms, including a universal mathematical semiotic system $Q$ (i.e. $Q \subset B_{n}$ ); $P$ are rules of addition (linking, output) of words from $A$ and $B_{n}$. As a result of using the rules for elements from $A$, set

$$
B_{T}=\left\{x \mid x=a_{i} \beta_{s}, a_{i} \in B_{n}, \beta_{s} \in P,(i=\overline{1,13},|s|<\infty)\right\}
$$

is formed, representing a set of terms obtained as a result of actions with elementary concepts.

Let us call set $G=\left\{A, P, \ldots, B_{n}\right\}$ a grammar, words $x=a_{i} \beta_{s}$ from a higher level (as compared to the elemen- 
tary vocabulary) dictionary; $B_{T}-$ terminological dictionary contained in the thesaurus. Then

$$
L(G)=\left\{x \mid x \in B_{T} \wedge A \stackrel{G}{\longrightarrow} x\right\}
$$

will be called a language (in our case a mathematical language of the secondary school). Let us consider a triple $\langle L(G), T, E\rangle$, where $T=\left\{T_{j}\right\}$ are specific instructional devices and their combinations (set $T$ is finite). In this case, the environments: individuals (microenvironments), teaching environment and other environments are combined. Let us bear in mind that a number of sub-environments are finite, and they tend to vary over the course of time. Therefore, the environment under study will be called an educational individual environment.

\section{Design philosophy of educational web-resources for a multicultural audience}

Based on the analysis of parametric theory of G. Hofstede [2] in the context of the educational process, research of A. Marcus [7], and the theory of cognitive styles of R. Nisbett [8], theoretical guidelines to manage the structure and design of cultural and adaptive Web User Interfaces have been developed. Here are some of them.

The following criteria are specific for the indicator "Individualism - Collectivism":

\section{- Metaphoras:}

$\downarrow$ Individualism: focuses on actions, instruments, objectives;

$\uparrow$ Collectivism: focuses on connections, relations between the objects, content;

\section{- Mental models:}

\Individualism: focuses on product, objective; targeting to implementation and maximization of personal goals and achievements;

$\checkmark$ Collectivism: focuses on the role, duty; models directed to socio-political and cultural goals and underestimating the significance of personal achievements;

\section{- Navigation system:}

- Individualism: global (overall) and a customized navigation system; individual areas (popular elections, elections of famous people); the system remains unchanged regardless of the user's role; the ability to customize some functions;

$\checkmark$ Collectivism: contextual navigation system; general and official elections focused on groups of people; the systems vary based on the user role;

\section{- Interaction:}

$\downarrow$ Individualism: keyword search; focuses on active measures; possibility of using several devices; usercustomized system.

$\checkmark$ Collectivism: limited interaction; officially adopted devices are available; management depends on the user role;

\section{- Visual component:}

$\checkmark$ Individualism: emphasis on personal success, benefit, objectives and purposes; success is expressed through materialism and consumerism; image of the younger generation, individuals, and active actions; the content is focused on personal achievements, new and unique products and concepts; expression of personal opinion of the users is welcome, discussions are encouraged; generally, users are not required to provide personal information; low context; active dynamic speech; direct access to the user as an individual;

- Collectivism: emphasis on institutional success, objectives and relationships; success is expressed through representation of social and political programs; images of adult and experienced leaders and groups of people are presented; the content highlights group achievements, history and cultural traditions, contains official slogans and elections; expression of a personal opinion is not encouraged; high context; official terminology; formal style of speech; appeal to the user as a part of society, pronounced unity with others.

For all other Hofstede model parameters, conformity expressed in the influence of cultural indicators on the specifics of user interaction with an Internet resource can be also traced.

\section{Conclusion}

The appearance of the information environment has initiated the emergence of educational cross-culture, which, in turn, led to a certain kind of system variations that, in one way or other, are reflected in transformation of elements of managing information and the educational environment. The criteria on which to base a new-formation multicultural educational environment able to provide a constructive knowledge transfer are represented as follows: communication criterion (change of traditional forms of communication in the "teacher - student" system), methodological (appearance of the cultural and adaptive methods of work with educational information), content (differentiation and possible inhomogeneity of the learning content in the 
educational process), information (development and use of educational resources taking into account the cultural specifics of information perception and management). These points must affect the transformation of some institutions of the existing information and educational environment and will entail the creation of adap- tive tutorial centers, cultural online simulators, as well as intellectual tutorial environments possessing a cultural mental capacity.

This multi-stage approach will enable us to make the knowledge transfer process in a multicultural environment more constructive.

\title{
References
}

1. Triandis H. (1993) Etic-emic analysis of individualism and collectivism. Journal of Cross-Cultural Psychology, vol. 24, no. 3, pp. 366-383.

2. Hofstede G., Bond M.H. (1984) Hofstede's culture dimensions: An independent validation using Rokeach's value survey. Journal of CrossCultural Psychology, no. 15 (4), pp. 417-433.

3. Zharov V.K., Taratukhina Y.V. (2015) Pedagogicheskii konstruktivizm v kross-kul'turnoi srede [Pedagogical constructivism in a cross-cultural environment]. Moscow: Yanus-K (in Russian).

4. Taratukhina Y.V., Zharov V.K. (2014) Osobennosti funktsionirovaniya informatsionno-obrazovatel'noi sredy sovremennoi vysshei shkoly [Specifics of an informational and educational environment in modern higher education]. Business Informatics, no. (28), pp. 44-50 (in Russian).

5. Zharov V.K., Klimova I.A. (2002) Leksicheskii minimum matematicheskikh terminov na russkom, angliiskom i kitaiskom yazykakh [Lexical minimum of mathematical terms in Russian, English and Chinese]. Moscow, Guangzhou: Yanus-K (in Russian).

6. Van Ryzin J., ed. (1980) Klassifikatsiya i klaster [Classification and clustering]. Moscow: Mir (in Russian).

7. Marcus A. (2002) User-interface design, culture, and the future. Proceedings of the Working Conference on Advanced Visual Interfaces, Trento, Italy, 22-24 May 2002, pp. 15-27.

8. Nisbett R.E., Peng K., Choi I., Norenzayan A. (2001) Culture and systems of thought: Holistic vs. analytic cognition. Psychological Review, no. 108 , pp. $291-310$.

\section{Поликультурная учебная среда: Проблемы и особенности трансфера знаний}

\section{B.K. Жаров}

доктор педагогических наук, профессор, заведующий кафедрой фундаментальной и прикладной математики

Российский государственный гуманитарный университет

Адрес: 125993, г. Москва, Миусская площадь, 6

E-mail:valcon@mail.ru

\section{Ю.В. Таратухина}

кандидат филологических наук,

доцент кафедры инноваций и бизнеса в сфере информационных технологий

Наииональный исследовательский университет «Высшая школа экономики»

Адрес: 101000, г. Москва, ул. Мясницкая, д. 20

E-mail:jtaratuhina@hse.ru

\begin{abstract}
Аннотация
В современном обществе преподавателям часто приходится сталкиваться с поликультурной студенческой аудиторией, как в традиционном формате, так и в процессе онлайн-обучения. Культура каждой страны, так или иначе, отражается на образовательном процессе и во многом обуславливает его. Это, в свою очередь, влечет специфичность учебного контента, целей, ценностей и задач образования, методов обучения, педагогического дискурса, специфики выстраивания образовательной траектории и т.д.

В настоящей работе прослеживается взаимосвязь влияния культуры на образовательные практики, выраженное в целевом, ценностном и коммуникационном форматах. Многие педагоги в качестве основной проблемы в данном контексте, помимо когнитивной, коммуникативной и психолого-педагогической специфики, выделяют проблему конструктивного трансфера знаний в поликультурной учебной среде. При этом под поликультурной средой мы подразумеваем не только национальные различия, но и различный предшествующий профессиональный «бэкграунд» (это касается студентов магистерских программ и т.д.).
\end{abstract}


В данной работе мы делимся опытом выделения критериев для возможности построения культурнокогнитивной модели общения со студентами (тактических и стратегических приемов развития различных типов дискурса), с целью оптимизации учебного процесса в поликультурной среде. Критерии, по которым должна строиться поликультурная образовательная среда новой формации, способная обеспечивать конструктивный трансфер знаний, представляются следующим образом: коммуникационный критерий (изменение традиционных форм коммуникации в системе «преподаватель - студент»), методический (появление культурно-адаптивных методов работы с учебной информацией), контентный (дифференциация и возможная неоднородность учебного контента в образовательном процессе) и информационный (разработка и использование образовательных ресурсов, учитывающих культурную специфику восприятия и работы с информацией). Перечисленные пункты, в свою очередь, не могут не отразиться на трансформации некоторых институтов существующей информационно-педагогической среды.

Ключевые слова: поликультурная учебная среда, культурно-когнитивный профиль, образовательная кросс-культура.

Цитирование: Zharov V.K., Taratukhina Y.V. Multicultural teaching environment: Problems and specifics of knowledge transfer // Business Informatics. 2014. No. 2 (36). P. 63-70. DOI: 10.17323/1998-0663.2016.2.63.70.

\section{Литература}

1. Triandis H. Etic-emic analysis of individualism and collectivism // Journal of Cross-Cultural Psychology. 1993. Vol. 24. No. 3. P. $366-383$.

2. Hofstede G., Bond M.H. Hofstede's culture dimensions: An independent validation using Rokeach's value survey // Journal of Cross-Cultural Psychology. 1984. No. 15 (4). P. 417-433.

3. Жаров В.К., Таратухина Ю.В. Педагогический конструктивизм в кросс-культурной среде. М.: Янус-К, 2015. 276 с.

4. Таратухина Ю.В., Жаров В.К. Особенности функционирования информационно-образовательной среды современной высшей школы // Бизнес-информатика. 2014. № 2 (28). С. 44-50.

5. Жаров В.К., Климова И.А. Лексический минимум математических терминов на русском, английском и китайском языках. М., Гуанчжоу: Янус-К, 2002. 134 с.

6. Классификация и кластер / Под ред. Дж. Вэн Райзин. М.: Мир, 1980. 390 с.

7. Marcus A. User-interface design, culture, and the future // Proceedings of the Working Conference on Advanced Visual Interfaces, Trento, Italy, 22-24 May 2002. P. 15-27.

8. Nisbett R.E., Peng K., Choi I., Norenzayan A. Culture and systems of thought: Holistic vs. analytic cognition // Psychological Review. 2001. No. 108. P. $291-310$. 